\title{
Separate Filing (Splitsing) In Criminal Case Management
}

\author{
Hidayat Abdulah ${ }^{1}$
}

\begin{abstract}
In the implementation of the criminal case handling a lot of things that can be done to perfect evidence is the failure by one of them is doing a separate filing (splitsing). In Article 142 Criminal Procedure Code stipulates that the public prosecutor has the authority to separate docket (splitsing) against each defendant if found lacking evidence and testimony, as well as other matters that are not included in the provisions of Article 141 of the Criminal Procedure Code. Separation of the case must be based on solely the purpose of examination. That's what makes the public prosecutor has the authority to determine the case file should be separated (splitsing) or not. The purpose for doing the separation of the case file (splitsing) is to facilitate the enforcement of the prosecutor when the court process, to strengthen the evidence for lack of evidence when the process of verification, then a criminal offense committed by the offender more than one and the same time one of these actors into the search list (DPO) which allow splitsing. Keywords: Separate Filing; The Criminal Case.
\end{abstract}

\section{Introduction}

To realize that law enforcement can be well integrated and can be perceived by the public role, we need a mechanism or system of work in crime prevention or violation. The working mechanism of the offense or crime prevention called by the criminal justice system or Cryminal Justice System. With regard to the criminal justice system in Indonesia, the relationship with the criminal case in the Book of Law Criminal Law (Criminal Code) regulated components of the criminal justice system, consisting of the legislator (maker of the Act), General Counsel, police, judiciary , Courts and Prisons. The six components of law enforcement functions, tasks, define between one another in accordance with the mechanism set out in the positive law.

That the Criminal justice in Indonesia signaled the start of a case originated from a report or complaint reported at the police and then to hold with a way to do an investigation, subsequently if that the case is criminal then the mechanism of his case will be raised to the level of investigation and at the time it is also a maximum of seven (7) days after the upgrade to the investigation the investigator must notify the commencement of the investigation to the complainant, and reported to the public prosecutor.

In performing its duties to handle criminal cases, investigators and prosecutors relationship can be both functional and instantional between investigators and prosecutors ${ }^{2}$, Functional and institutional relationship between the components of the criminal justice Police and Prosecutors have been intertwined since the start of the investigation of the notification.

Understanding the commencement notice of the investigation, it can be formulated as follows: "Notice of the commencement of the investigation it is a notice of investigation to the public prosecutor, said investigators have begun conducting investigations into a specific criminal offense" ${ }^{13}$, The basis for coordination in the proceedings between the

\footnotetext{
1 Student of Masters (S2) of Law Faculty of Law Unissula Semarang and Police member email:hidayatabdulah2@gmail.com

${ }^{2}$ Harun M. Husein 1991 Penyidikan dan Penuntutan dalam Proses Pidana Jakarta:PT Rineka Cipta p. 269.

${ }^{3}$ Ibid.,p. 271.
} 
public prosecutor is investigating the basic article in the judicial process for coordination between the investigator with the prosecutor is Article 109 of the Criminal Procedure Code. Investigators must inform the public prosecutor that the investigators have begun to investigate an incident that constitutes a criminal act or an investigator to stop the investigation because there is not enough evidence or the event is not a crime or the investigation terminated by operation of law. Djoko Prakoso said that the relationship investigator and public prosecutor can then be addressed in terms of investigation requires the extension of detention to the public prosecutor in connection with the interest unfinished examination set forth in Article 24 paragraph (2) Criminal Procedure Code ${ }^{4}$,

The public prosecutor in the duties required to prove that the defendant was guilty of a criminal act as indicted against unfounded since the level of investigation. Relations since the level of investigation to prosecution level is strong. The inter-relationship let see the provisions of Article 110 paragraph (4) and Article 138 Paragraph (1) and (2) Criminal Procedure Code. Article 138 paragraph (1) Code of Criminal Procedure states that the public prosecutor after receiving the results of the investigation of the investigators soon learn and examine it and within seven days notify the investigator if the results of the investigation is complete or not, whereas Article 138 paragraph (2) Criminal Procedure Code states that in the case of results of the investigation is not yet complete, ${ }^{5}$, That the notification referred to in Article 110 paragraph (4) Criminal Procedure Code it is a notice of the public prosecutor about the results of the investigation, including whether the results of the investigation is complete or not ${ }^{6}$,

On Article 142 Criminal Procedure Code stipulates that the public prosecutor has the authority to separate docket (splitsing) against each

defendant if found lacking evidence and testimony, as well as other matters that are not included in the provisions of Article 141 of the Criminal Procedure Code. Separation of the case must be based on solely the purpose of examination. That's what makes the public prosecutor has the authority to determine the case file should be separated (splitsing) or not, and the separation process docket usually do is investigating after a user of the public prosecutor.

\section{Results And Discussion}

\subsection{Understanding Separation Case file (Splitsing)}

Splitsing can mean separation or splitting docket. Separation according to Indonesian Dictionary gives the definition of the process, how, act to separate or segregate then splitting (cleavage and so on) ${ }^{7}$. Solving according to Indonesian Dictionary gives the definition of the process, the way, the act break or solve ${ }^{8}$, The definition of two words and the separation of the solution, together provide a picture that there is no sense of separation to distinguish between dossiers with solving the case file, as in the definition of separation succession mean splitting (cleavage and so on) in accordance with the said

\footnotetext{
${ }^{4}$ Djoko Prakoso 1985 Eksistensi Jaksa di Tengah-tengah Masyarakat Jakarta: Ghalia Indonesia p. 67.

${ }^{5}$ Harun M. Husein Op. Cit. P. 216.

${ }^{6}$ Ibid.,p. 216-217.

${ }^{7}$ Departemen Pendidikan Nasional 2002 Kamus Besar Bahasa Indonesia Edisi Ketiga Jakarta: Balai Pustaka p. 879.

${ }^{8}$ Ibid.,p. 840.
} 
resolution.

The Book of Criminal Law in splitsing relevant provisions of Article 142 reads: Article 142. In the event that the public prosecutor receives the case file containing some criminal offenses committed by some of the suspects who are not included in the provisions of Article 141, the public prosecutor can charge against each defendant separately.

The Criminal Procedure Code explicitly testified that splitsing is the separation of the case file. Article 142 Criminal Procedure Code also provides an explanation of the guidelines implementation of the Criminal Procedure Code that splitsing usually done by creating a new case file in which the role of each suspect be witnesses, so that it is necessary to do a new examination of both the suspects and witnesses ${ }^{9}$, What is written in the guidelines are not entirely proper implementation of the Criminal Procedure Code ${ }^{10}$, Not always the case were broken (splitsing) should be checked again, perhaps when there are no witnesses, while there are some people suspect such things correctly then suspect turns into a witness.

Separation of the dossier provided for in Article 142 Criminal Procedure Code is the opposite of the rule of Article 141 of the Criminal Procedure Code authorizes a general pununtut to separate the case files of one file into multiple docket.

Basic separation of the dossier is the existence of the criminal that more than one person, then the public prosecutor discretion under Article 142 Criminal Procedure Code, the public prosecutor to separate docket (splitsing).

The purpose for doing the separation of the case file (splitsing) is to facilitate the enforcement of the prosecutor when the court process, to strengthen the evidence for lack of evidence when the process of verification, then a criminal offense committed by the offender more than one and the same time one of these actors into the search list (DPO) which allow splitsing. Separation of case files into a stand-alone case, between a defendant with the other defendants, each of which can be used as a witness on a reciprocal basis ${ }^{11}$,

Not always in split case need a new examination, if there are several suspects and also some witnesses then in separating the suit only need to create a duplicate of course, where the list of suspects (the accused) was converted into individually and examination of witnesses remain, in this case the prosecutor may direct the case file splits into several pieces with a request duplicate results of the examination of the investigator ${ }^{12}$,

Given that the case should be distinguished incomplete (lack of witnesses) so as to be separated where the alleged witness to each other that must be resolved through Article 138 Criminal Procedure Code, with the separation of the dossier to be more than one without adding inspection ${ }^{13}$,

\subsection{Understanding Crime}

Crime as well as the offense, the offense comes from the Latin word delictum, in German called delict, in French called Delit. Dutch criminal law uses the term strafbaar feit.

\footnotetext{
${ }^{9}$ Andi Hamzah 1985 Pengantar Hukum Acara Pidana Indonesia Jakarta: Ghalia Indonesia p. 164.

${ }^{10}$ Ibid.,p. 165.

${ }^{11}$ Yahya Harahap 2006 Pembahasan Permasalahan dan Penerapan KUHAP Penyidikan dan Penuntutan (Edisi Kedua) Jakarta: Sinar Grafika p. 442.

${ }^{12}$ Andi Hamzah 1985 Pengantar Hukum Acara Pidana Indonesia Op. Cit. P. 165.

${ }^{13}$ Ibid.,p. 165-166.
} 
Criminal law Anglo-Saxon countries, to use the term criminal offense or act for the same purpose $^{14}$,

According to the Dutch language, an offense referred to by "strafbaar feit". The phrase "feit" itself in the Dutch language means "a portion of a true" or "gedeelte een van de werkelijkheid"15, Was "strafbaar" means "can be punished", so literally the words "strafbaar feit" translated as "part of a reality that can be punished", which of course is not right, because one day we will know that it can be punished it is actually the human being as a person and not the fact, act or action ${ }^{16}$,

Indonesian dictionary gives the definition, meaning the offense is "The act punishable as a violation of the law; criminal act"17 ${ }^{17}$, The criminal action is prohibited by the law, which ban the threat that (sanctions) in the form of a specific criminal, for anyone who violates the ban ${ }^{18}$, Indonesian Penal Code WVS rooted in the Netherlands, then the original term is the same, strafbaar feit ${ }^{19}$, The use of the words by forming a criminal offense under the Penal Code Act provides a definition always without explanation menegenai what exactly what constitutes the criminal act.

According to Pompe cited by PAF Lamintang, the words "strafbaar feit" that theoretically can be defined as "a violation of norms (disruption of legal order) who intentionally or unintentionally been done by an actor, where sentencing of the offender is necessary the sake of maintaining law and order and ensuring the interests of the law "or as" de normovertreding (verstoring der rechtsorde), waaran de overtreder Schuld heeft en waaran de bestraffling dienstig is voor de handhaving der rechts en de orde van het algemeen behartiging welzijn " 20 ,

He acknowledges "it's very dangerous look for an explanation of the positive law which is solely for the use of theoretical opinion". Whereas, according to the State Indonesian positive law, a "strafbaar feit" it actually is nothing other than an act that the law is something the formulation has been declared a punishable act ${ }^{21}$, It could be argued that to convict is not enough if there are a "strafbaar feit" but there must also be "strafbaar person" or someone can be punished, where the person can not be punished if the "strafbaar feit" which he did not "wederrechtelijk" which had he done intentionally or unintentionally.

According to Van Hattum cited by PAF Lamintang found something that action can not be separated from those who have committed such acts ${ }^{22}$, Because the word "strafbaar feit" it was as if "a person can be punished" was abolished, it is usually when people describe something offense into its elements, people fixated on the elements of the offense as defined in the legislation and forget about the existence of other conditions that can make a person could be punished, including requirements relating to personal of the culprit

\footnotetext{
${ }^{14}$ Andi Hamzah 2012 Asas-Asas Hukum Pidana di Indonesia \& Perkembangannya Jakarta: SOFMEDIA p. 118.

${ }^{15}$ Van bemmelen ons strafrecht I hlm. 62 dalam P.A.F. Lamintang 1997 Dasar-Dasar Untuk Mempelajari Hukum Pidana Yang Berlaku Di Indonesia Bandung: PT Citra Aditya Bakti p. 181.

${ }^{16} \mathrm{lbid}$.

${ }^{17}$ Departemen Pendidikan dan Kebudayaan Kamus Besar Bahasa Indonesia Balai Pustaka 2001 dalam Leden Marpaung 2006 Asas-Teori-Praktik Hukum Pidana Jakarta: Sinar Grafika p. 7.

${ }^{18}$ Djoko Prakoso 1988 Pemecahan Perkara Pidana (Splitsing) Op. Cit p. 79.

${ }^{19}$ Ibid.

${ }^{20}$ Pompe Handbook p. 39 in PAF Lamintang 1997 op. Cit p. 182.

${ }^{21}$ Ibid., p. 183.

22 Ibid.,p. 184.
} 
itself $^{23}$,

All the conditions must have been met as a requirement that a person can be tried must also be considered as elements of the offense ${ }^{24}$,

Moeljatno use the term criminal acts as prohibited by a rule of law which the prohibition of the threat that (sanctions) in the form of a specific criminal, for anyone who violates the ban $^{25}$, Wearing speech act refers to two concrete circumstances: first, the presence of certain events and second, the man whose actions are causing the incident ${ }^{26}$,

The term offense is also approved by him, among other things said that "acts" as the word is not so well known, the legislation uses the word "criminal act" well within the chapters themselves, as well as in his explanation almost always wears also the word "deed" ${ }^{12}$,

\subsection{Elements of Crime}

That there are two views, namely the monistic view where this view see the overall requirement for the crime that all of the nature of the act. Dualistic view of where the deviation from the monistic view, a criminal act does not include criminal liability.

Monistic view of considering a person for a criminal offense can already convicted, while the dualistic view is not yet sufficient condition for convicted they must be accompanied by accountability requirements criminal responsibility should exist in people who do ${ }^{28}$, The next difference principle to impose a dualistic class ie the actus non facit reum nisi mens rea as the separation between the prohibited act (actus reus) and can be held accountable maker dipertanggung crime (mens rea).

Experts express opinions related to the elements of a criminal offense, as described below:

- Moeljatno, provide an overview that can be called a criminal offense when included in a criminal act (the existence of an act, fulfill the formulation of legislation, the nature against the law) is then coupled with an error as criminal liability according Muljatno has been attached to the person who acts as the the elements including any criminal act quite legitimate criminal acts.

- Pompe, provide an overview that can be called a criminal offense if the existence of a criminal act and a threat, it will suffice to say the existence of a criminal offense. Although Pompe adds an element of nature against the law then a mistake, because reasoned not absolute nature of their crime.

- Simons, provide an overview that can be called a criminal act when there is an element of an act, the criminal threat, is against the law, any error, that person is able to be responsible as when one of these elements is not there then there is no crime ${ }^{29}$,

\section{Closing}

\subsection{Conclusion}

Splitsing means separation, separation according to Indonesian Dictionary gives the definition of the process, how, act to separate or segregate then splitting (cleavage and so

\footnotetext{
${ }^{23}$ Van Hattum Hand-en Leerboek I p. 112 in Ibid. P. 185.

${ }^{24}$ Van Hattum Ibid.

${ }^{25}$ Moeljatno 1987 Azas-Azas Hukum Pidana Jakarta: PT Bina Aksara p. 54.

${ }^{26}$ Ibid.

${ }^{27}$ Andi Hamzah 2012 Op cit. P. 119.

${ }^{28}$ Sudarto 1990 Hukum Pidana I Semarang: Yayasan Sudarto p. 45.

${ }^{29}$ Ibid.,p. 49.
} 
on)

The Code of Criminal Procedure explicitly testified that splitsing is the separation of the case file. Article 142 Criminal Procedure Code also provides an explanation of the guidelines implementation of the Criminal Procedure Code that splitsing usually done by creating a new case file in which the role of each suspect be witnesses, so that it is necessary to do a new examination of both the suspects and witnesses.

The purpose for doing the separation of the case file (splitsing) is to facilitate the enforcement of the prosecutor when the court process, to strengthen the evidence for lack of evidence when the process of verification, then a criminal offense committed by the offender more than one and the same time one of these actors into the search list (DPO) which allow splitsing.

\subsection{Suggestion}

That according to the provisions of Article 142 Criminal Procedure Code, which reads Article 142 . In the event that the public prosecutor receives the case file containing some criminal offenses committed by some of the suspects who are not included in the provisions of Article 141, the public prosecutor can charge against each defendant separately.

Then top it authorized a charge against each defendant separately is the prosecutor, the investigator should be doing filing the case if they want to separate filings (splitsing) good coordination terlebbih advance to the Public Prosecutor in order not to violate the provisions in the Criminal Code.

\section{Bibliography}

[1] Andi Hamzah, 1985, Pengantar Hukum Acara Pidana Indonesia, Jakarta: Ghalia Indonesia 2002, Hukum Acara Pidana, Sinar Grafika, Jakarta. .2012, Asas-asas Hukum Pidana Di Indonesia \& Perkembangannya, Jakarta: SOFMEDIA.

[3] Djoko Prakoso., 1985, Eksistensi Jaksa Di Tengah-tengah Masyarakat, Jakarta: Ghalia Indonesia

[4] 1988, Pemecahan Perkara Pidana (splitsing), Yogyakarta: Liberty

[5] Harun M Husein., 1991, Penyidikan dan Penuntutan Dalam Proses Pidana, Jakarta: PT Rineka Cipta.

[6] Lamintang, P.A.F., 1997, Dasar-dasar Untuk Mempelajari Hukum Pidana Yang Berlaku Di Indonesia, Bandung: PT Citra Aditya Bakti.

[7] Moeljatno, 1987, Azas-Azas Hukum Pidana, Jakarta: PT Bina Aksara.

[8] Pendidikan Nasional, Departemen., 2002, Kamus Besar Bahasa Indonesia Edisi Ketiga, Jakarta: Balai Pustaka.

[9] Sudarto., 1990, Hukum Pidana I, Semarang: Yayasan Sudarto.

[10] Yahya Harahap., 2006, Pembahasan Permasalahan dan Penerapan KUHAP Penyidikan dan Penuntutan (Edisi Kedua), Jakarta: Sinar Grafika.

[11] Act No. 8 of 1981 on Criminal Proceedings. 